\title{
What journalists reminder us of: representation of a crucial international event in turkish press - Malta Summit of 1989
}

\author{
Banu Dagtas \\ Anadolu University, Turkey \\ E-mail: banudagtas@gmail.com
}

\begin{abstract}
The role of media in crafting storing, retrieving, reactivating, preserving and shaping collective memories is now a thriving field of. This work, combined with van Dijk's (1988a; 1988b; 2011) studies of news discourses, alows us consider in more detail, the role of journalists-as an ideological groupin shaping collective memories through their social representations of news events. This study explores this process through an analysis of the way Turkish journalists represented one of important international events of recent years, the "Malta Summit" meeting between US President George Bush and Soviet leader Mikhael Gorbachev on December 2-3, 1989 in Malta. Prior to it taking place, most East Euro-

pean countries had already begun the process of political transformation. The summit resulted in the declaration of the "end of the Cold War" and important decisions concerning the disarmanent process. For the purposes of this study, five days of news coverage acrosss a representative sample of the Turkish opinion press (Cumhuriyet, Güneş and Tercüman), popular press (Hürriyet, Sabah and Günaydın) and quasi-opinion/popular press (Milliyet) were selected for analysis. The analysis addressed thematic and schematic structures at the macro structural level; local semantics and local coherence at the microstructural level; together with the lexical style of the news and the content of the news photographs. ${ }^{1}$
\end{abstract}

Keywords: collective memory; turkish journalism; Malta Summit News; discourse studies; Teun van Dijk.

\section{INTRODUCTION}

$\mathrm{T}$ recent years, the construction and reconstruction of collective memory has emerged as an 1 imporant field of scholarly study with a significant stream of work focusing on the the role of media in its storage, retrieval, reactivation, preservation and shaping (see Connerton, 1999; Halbwachs, 1992; Huyssen, 2000; Houskins and O’loughlin, 2010; Maltby, 2016; Misztal, 2003;

Data de submissão: 2017-03-20. Data de aprovação: 2017-05-04.

A Revista Estudos em Comunicação é financiada por Fundos FEDER através do Programa Operacional Factores de Competitividade - COMPETE e por Fundos Nacionais através da FCT - Fundação para a Ciência e a Tecnologia no âmbito do projeto Comunicação, Filosofia e Humanidades (LabCom.IFP) UID/CCI/00661/2013.

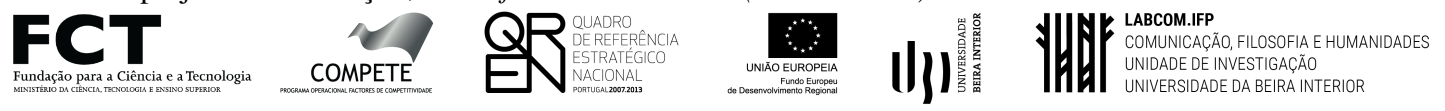

1. The data of the news texts are taken from my unpublished MA thesis- "Structure of Foreign News in Turkish Popular and Opinion Papers (Application of Discourse Analysis Methodology on the Basis of News Portrayal of Malta Summit"). METU, 1992. 
Zelizer, 1992; 2014). Zelizer's (2014) research, which explores the role of journalism asks whether collective memory could exist without some journalistic function and maintains that it could not. Olick (2014) reflects on the barriers and biases that have inhibited a fuller analysis of the connections between journalism and memory and proposes more focus on the subject. According to Olick (2014: 18), both the records of event that news coverage provides and the 'memories of journalism' are a central part of our collective memories.

Other writers have considered how personal, individual memory intersects with shared, collective, cultural, public forms of memory (See for example Kuhn 2002; 2010). As Maltby (2016: 642 ) points out however, less attention has been paid to the ways in which memory (she suggest the concept of remembering) is enacted and performed with media and how these processes become intrinsically linked to issues of identity, power, and agency in the competition to privilege one's own remembering. She asks the question "how negotiations of remembering and identity can shape and be shaped by representations prevalent in the media".

In this study, I am applying van Dijk's (1988a; 1988b; 2011) studies of news discourses as a particularly productive point of entry into the question of how journalistic accounts help to shape collective memory by providing readily avilable and resonant linguistic and visual resources for defining and interpreting key events. He argues that the the macrostrcutures provided by news coversage and commentary play a key role in organising the comprehension processes of the readers. According to van Dijk, the cognitive operations employed in these macrostructures, are central to both the processes of the news production by reporters and editors and the comprehension and storage (memory) processes of readers (1988a). He argues (1988b) that they are rooted in a shared ideology of journalists' news making, a "journalistic code", that was initially established by the Western media and news agencies and then spread around the World, including to Turkey during the counry's process of modernisation.

This study analyses how Turkish journalists represented the one of the most important international events of recent decades, the summit meeting that took place in Malta, between US President George Bush and Soviet leader Mikhael Gorbachev on December 2-3, 1989. Prior to it taking place, most East Eurepean countries had already begun the process of their political transformation. The Berlin Wall had come down and the question of the unification of the two Germanies had entered the agenda of World politics. The 'Malta Summit' as it came to be called, resulted in the declaration of the "end of the Cold War" and in important decisions concerning the disarmanent process. It was covered by most of newspapers as spot news and given front page treatment.

For the purposes of this study, five days of news coverage given to the summit by a cross secion of the Turkish were selected for detailed study. The titles chosen were drawn from the opinion press (Cumhuriyet, Güneş and Tercüman), the popular press (Hürriyet, Sabah and Günaydın) and the quasi-opinion/popular press (Milliyet) ${ }^{2}$. The analysis of the coverage focuses on the thematic

2. In 1989 the concentration of the Turkish media was not realized yet and the owners of the newspapers were seperate. Among the selected newspapers (indeed they were nearly well representative of the whole Turkish press); Cumhuriyet (1924) is the oldest one and the up to mid 1960 it was the press of young Republic (1923) and the party of CHP (People's Republic Party-now main opposition party). By the mid 1960s, Cumhuriyet became representative of the leftist press. In 1989, Cumhuriyet was the representative of the moderate left. The second oldest newspaper is the 
and schematic structures operating at the macro structural level; local semantics and local coherence at the microstructural level; and the lexical style of the news and the content of the news photographs at the micro level.

The establishment of the Turkish Republic in 1923 was the outcome of a long process of voluntary Westernization/modernization in which journalists played a prominent role as members of a top-down modernizing elite. So, when we ask how Turkish journalists, writing at the end of Cold War and the beginning of globalization, represent and store the news event of the Malta Summit is important to recognise that the accounts they offer are grounded in understandings of Turkey's own process of transformation and westernisation from the beginning of the 19th century onwards.

\section{NEWS EVENTS AND COLLECTIVE MEMORIES}

In order to address the question of 'what the journalists remind us of ' or 'what we are remembering with media representations' it is first necessary to clarify what we mean with "collective memory", since media has a crucial role in the formation and sustainability of collective memories. But firstly, lets begin by exploring the reasons why there has an accelareting scholarly interest in work on collective memory in recent years. Huyssen argues that whereas earlier approaches priviledged attention to the future, shifting understandings of modernity have now directed attention increasingly to the past so that "the focus has shifted from present futures to present pasts" (Huyssen 2000: 21).

He argues that the forthieth and fiftieth anniversaries of events in the history of the Third Reich played a central role in the acceleration of memory discourses in the Western world in the 1980s with the book burnings remembered in 1983; the organized pogrom of 1938 aganist Germany's Jews publicy commemorated in 1988; and the Wannsee conference of 1942 initating the 'Final Solution' remembered in 1992 (Huyssen, 2000: 21).

It now generally acknowledged that collective memory studies began with Halbwachs' (1992) work - On Collective Memory - in which he argues that "memories are social". According to Halbwach (1992: 22), " memory" is socially determined; where the shared experiences of a social group and their common reserve of remembrance culminates in the formation of a collective memory. For Halbwach, then, memory is always a reconstruction of the past that builds upon previous pasts, but always in relation to the social group. As Assmann (1995) underlines, Halbwach's work established "memory as an object of sociological study and shifted the conceptualization of memory out of a biological framework and into cultural one" (quoted in Misztal, 2003: 45).

\footnotetext{
Hürriyet (1948) - representative of the liberal and popular press, from the beginning. And by 1989 and up to recent times, its role has been accepted as the 'flagship' of the Turkish press. Milliyet (1950) was another old leftist press and its policy was between opinion and popular by 1989. In 1979 the "legend general editor" of the Milliyet - Abdi İpekçi was assasinated by Mehmet Ali A $\breve{g} c a$ who had become the assassin of the Papa II. Ioannes Paulus. Tercüman (1955) was the representative of the nationalist-right press in 1989 and before. Günaydin (1968) was the well example of the popular press by 1989. Güneş (opinion) (1982) and Sabah (popular) (1985) were the new papers of that time. By 1989 Hürriyet and Sabah had the highest circulation rates and by 1990's they had become the representative of the two big conglameres of Turkish media (Hürriyet was belong to Doğan Group and Sabah was belong to Sabah Group-Dinç Bilgin).
} 
Another influential contribution which focuses on the collective side of memories is Connerton's (1999) work - How Societies Remember in which he argued that, "even in case of personal memory, we deal with the other people's group of ideas; persons, places, dates and words of the memory actualized together with the material and non-material lifes of the society that we live within" Connerton (1999: 60).

The other foundational work is Misztal's (2003) book - Theories of Social Remembering in which he asserts that "memory is also social because remembering does not take place in a social vacuum. We remember as a members of the social groups, and this means assuming and internalizing the common traditions and social representation shared by our collectivities" (Misztal, 2003:

12). Mistzal, underlines the centrality of social context:

"Memory can not be removed from its social context, since whenever we remember something - for example, our first day at the university - we also recall the social circumstances in which the event took place: the city, the university, friends and so on. Morever, collective memory constitutes the shared social frameworks of individual recollections as we share our memories with some people and not others, and- in turn- with whom, for what purpose and when we remember, all of which contributes to what we remember" (Misztal, 2003: 12).

According to Schudson (1997), memory is also social, because the act of remembering is itself interactive, promoted by cultural artefacts and cues employed for social purposes and even enacted through cooperative activity (quoted in Misztal, 2003: 12).

Another influential contributor to the formation of collective memory studies, Huyssen, underliens this point, arguing that "the past does not live in the memory with its purity, the past become a memory with the representations" (Huyssen, 1999: 13). Huyssen sees older sociological approaches to memory like Halbwachs', that posit relatively stable formations of social and group memories, as no longer adequate to grasp the current dynamics of media and temporality, memory, lived time and forgetting, in a situation where: "The clashing and ever more fragmanted memory politics of specific social and ethnic groups raise the question whether the forms of collective consensual memory are even still possible today, and if not whether and in what form of social and cultural cohesion can be guaranteed without them" (Huyssen, 2000: 28). Another pertinent question is asked by Maltby who asks us to consider : "which memory is enacted and performed with media and how these processes become intrinsically linked to issues of identity, power, and agency in the competition to privilege one's own remembering" and "how negotiations of remembering and identity can shape and be shaped by representations prevalent in the media" (Maltby, 2016: 642).

At this point, it is productive to introduce van Dijk's critical approach to analysing news discourses into the discussion, since his work provides us with tools for exploring the link between memory and the processes of news production and consumption. According to van Dijk (1988b: 107), "memory", is cognitively designed to serve social needs. It involves information but also social communication. Since "the acquisition of knowledge and beliefs through discourse in the lives of people has continually taken place in contexts of socialization, interpersonal and intergroup perception, and interaction. We may conclude, therefore, that, apart from a few universal principles of human information processing, cognition is essentially social" (van Dijk, 1988b: 107). 
For van Dijk "discourse production is not just the expression and communication of models or individual opinions. Rather, each speaker is engaged in social action and, therefore, speaks as a group member. To form a sociocognitive theory of (news) production, however, we must understand the consequences of this general statement" (van Dijk, 1988b: 110). He goes on to argue that this cognitive framework suggests how text or event information is analyzed, interpreted, and represented in memory, and these processes also hold for the analysis of events as potential news events. An event thus analyzed is represented as a model in episodic memory. Such a model features the dominant actions or events, participants, time and location, circumstances, relevant objects, or instruments of action, organized in a hierarchical structure (van Dijk, 1988b: 111).

When the news is accepted as discourse, it can no longer be considered only as an isolated textual structure but becomes a complex communicative event - embodying a social context which inolves participants and processes of production and consumption. Van Dijk (1988b: 99) underlines that, "journalists participate in news encounters and write news articles as social members. This fact also affects their knowledge, beliefs, attitudes, goals, plans, or ideologies, all of which are also partly shared by a professional or wider social group". In this context, news production is accepted as a complex process in which the knowledge, beliefs and opinions of journalists are matched with existing or incoming information about event. According to van Dijk (1988b: 112), "the result of event perception and interpretation, then, is a subjective but socially-monitored model of the situation in the memory of an observing reporter".

In his model linking news discourses with the sociocognitive theory of news production, the theoretical term semantic macrostructure plays a key role. Macrostructures explain "how newsmakers continuously and routinely summarize the myriad of source texts (other media messages, wires, interviews, reports, or press conferences) that are used in the production of a specific news report... Macrostructures also explain why most readers usually only remember the main topics, that is, the higher levels of the macrostructure of a news reports" (van Dijk, 1988a: 14).

Macrostructures (topics) as well as the news schema that organizes them do not appear in the text in a continuous way however. Rather, they tend to appear in an installment-type, discontinuous way. The top of the macrostructure of a news report generally tends to be expressed first; that is, first the headline (the highest macroproposition), then the lead (the top of the macrostructure), and subsequently the lower macropropositions of the report, with details of content and the less prominent schematic categories (e.g., history or comments) towards the end. This is an effective strategy which allows stylistic variation by each reporter or newspaper. For the reader it means that in principle the beginning of the text always contains the most important information (van Dijk, 1988a: 15). Thematic analysis, as part of the macrostructural analysis, shows both the ordering of topics and their semantic function, eg. cause, consequence and actors. Conventional roles of topics in news stories, such as the giving of the information about the news event, context, history and verbal reactions are examined as part of the schematic analysis.

Lexicalization (word choice) and overlexicalization are also important devices revealing the ideological meanings carried by news discourse. Some lexical choices do not originate in sociopolitical ideology but are part of professional registers used to denote specific event characteristics, as in case of the use of stereotypical terms. Van Dijk (1988b: 81), stresses that lexical style may be controlled by rhetorical strategies, such as those of "understatement". "Mitigations", especially 
used when describing negative acts of important news actors, are a routine procedure, used also to avoid charges of libel. The stereotypical term "controversial,"for instance, is used routinely to denote characteristics of a person that are considered negative by the journalist or other important reference groups (van Dijk, 1988b: 82). News about foreign affairs employs a special lexical style register. As van Dijk notes: "Not only are the words used in accordance with the formal style of newswriting in general but also the account of international politics, which is the prevailing component of foreign news, requires both delicacy and some typical political jargon borrowed from diplomats and politicians" (van Dijk 1988a: 108).

To analyze the microstructure of the news, local semantic analysis is used to examine how and in which order macropropositions are specified in the text; while local coherence analysis examines the type of relationship between them. Specification topics relate both the main event and background of a news item, eg. time, location, numbers, actors, evaluations and content of the statements.

In case of the local coherence of the news texts, "conditional relations of cause/consequence or the associated temporal relation of before/after, which are essential in storytelling, may be replaced by functional relations of specification in news discourses: A higher level statement about a global event or action may in a subsequent sentence be further clarified with details" (van Dijk, 1988b: 65). Since news discourse is organized from top (general) to bottom (details) and the relation between general topics and microdetails is given by the specification relations previously presented, news stories should follow functional links (e.g., specification, generalization, contrast, explanation, or content of previously mentioned statements, etc.) of specification, rather than the cause-consequence links found in natural stories (van Dijk, 1988a: 104).

Rhetorical operations also effect the structure of news at all levels (van Dijk, 1988a: 16). Their role is to make texts more persuasive and to satisfy the basic cognitive and emotional conditions for the effective processes of information. A manipulation of figures and quotations, syntactic and semantic operations such as parallelism, comparison and metaphor, lexical style and exaggrated use of photographs are all examples of commonly applied rhetorical operations. For van Dijk:

\footnotetext{
“... whereas news style is heavily constrained by various contextual factors deriving from the public, mass-mediated, and formal nature of news, the use of rhetorical structures in the news depends on the goals and intended effects of communication". Stylistic choices indicate the kind of discourse for a particular situation or the presupposed ideological backgrounds. The recourse to rhetoric is not dictated by context in this way. It may be freely engaged in, if only to make the message more effective" (van Dijk, 1988b: 82).
}

Having outlined the basic components of van Dijk's discourse analysis appraoch to the new production of resources for collective memory we now turn to case study of the way the "Malta Summit" (1989) was presented in the Turkish press. 


\section{Findings of The discourse analysis of news Coverage of The Malta Summit}

\section{Macrostructural Analysis}

\section{Thematic analysis}

The intention of this section is to focus on headlines and topic derivation in each newspaper. Table 1 shows the headlines. It can be seen that all of the papers studied share a general belief in the summit as "functional to the realization of world peace" and the "end to the cold war era". Differences between opinion and popular papers in terms of headline content lies in the lexicalization, popular papers making considerable use of informal language in their headlines.

Table 1. The List of Headlines

\begin{tabular}{|c|c|c|}
\hline Newspapers & Date & Headlines \\
\hline \multirow[t]{11}{*}{ Cumhuriyet } & Dec 1, 1989 & Malta awaits supers \\
\hline & Dec 2, 1989 & Ankara looking at summit with suspicion \\
\hline & Dec 2, 1989 & West awaits surprise with suspicion \\
\hline & Dec 2, 1989 & From Yalta to Malta \\
\hline & Dec 2, 1989 & Gorbachev's 5th summit \\
\hline & Dec 2, 1989 & Bush careful and cautious \\
\hline & Dec 3, 1989 & Barganing of the superpowers \\
\hline & Dec 3, 1989 & EC following summit with suspicion \\
\hline & Dec 3, 1989 & Big Show on the ship \\
\hline & Dec 4, 1989 & The World is being renewed \\
\hline & Dec 5, 1989 & Bush; "we have ended the cold war" \\
\hline \multirow[t]{8}{*}{ Güneş } & Dec 1,1989 & Turning point in Malta for new peace \\
\hline & Dec 1,1989 & Security mobilization in Malta \\
\hline & Dec 1,1989 & 4 summits within 4 years among the superpowers \\
\hline & Dec 2, 1989 & World's eyes on Malta \\
\hline & Dec 2, 1989 & New era with Malta \\
\hline & Dec 5, 1989 & Happy ending to the supers' summits \\
\hline & Dec 5, 1989 & Where is Turkey in Malta? \\
\hline & Dec 5, 1989 & Turkey's four suspicions \\
\hline \multirow[t]{2}{*}{ Tercüman } & Dec 4, 1989 & Hot meeting in the cold wheather \\
\hline & $\operatorname{Dec} 4,1989$ & Superpowers meet with difficulty \\
\hline \multirow[t]{8}{*}{ Milliyet } & Dec 1,1989 & Malta is ready for summit \\
\hline & Dec 1, 1989 & Summit in the stormy sea \\
\hline & Dec 1, 1989 & Eyes of supers on their gardens \\
\hline & Dec 3, 1989 & Summit got seasick \\
\hline & Dec 3, 1989 & Attention to Yalta Syndrome \\
\hline & Dec 4, 1989 & Hot winds in the storm \\
\hline & Dec 4, 1989 & Hope for the World \\
\hline & Dec 5, 1989 & Malta Breeze in NATO and Warsaw Pac \\
\hline
\end{tabular}




\begin{tabular}{lll}
\hline Hürriyet & Dec 1,1989 & Broadside of peace in Malta \\
& Dec 2,1989 & Bush and Gorbachev met in 'Love Boat' \\
& Dec 2, 1989 & Warm meeting in cold waters \\
& Dec 4, 1989 & US-Soviet honeymoon in Mediterian \\
& Dec 5, 1989 & Soviets submit to liberal econmy \\
\hline Sabah & Dec 1,1989 & How much friendship is Bush's in speeches? \\
& Dec 1,1989 & How will Gorbachev make a surprise \\
& Dec 1, 1989 & From Roosevelt and Stalin to Bush and Gorbachev \\
& Dec 4, 1989 & Shadow of Philiphines at summit \\
& Dec 5, 1989 & Strange meeting in Moscov \\
\hline Günaydın & Dec 3,1989 & Sweeping Europe clear again \\
& Dec 3,1989 & The barganing has started \\
& Dec 3,1989 & Two knots in the summit \\
& Dec 4,1989 & Yes to peace \\
Dec 5, 1989 & Quit NATO and look to Europe \\
Dec 5,1989 & Everyone is happy \\
\hline
\end{tabular}

\section{Topic derivation}

In the analysis of topic derivation, texts are examined and individual topics identified by sentences occuring in paragraphs. Each topic or macroproposition must semantically subsume several propositions in the text. At the same time, each topic is associated with a hypothetical semantic function, for example, cause, consequence, actor, place. In all the papers selected for analysis news concerning the main event was assigned to thematic categories: the site, agenda, realization, events and outcome of the summit. The canonical order of topics was seen in general to follow the sequence of circumstance, statements, agenda, actors, event occurences, consequences, results and background topics with the exception of the irregular ordering of some news events.

The content of the main event topics are nearly same in all the papers as follows: The preparations and agenda of the summit, the weather conditions and the results of the summit. Presentations of the results focus on disarmanent, economic cooperation between two countries, the future of Eastern Europe, disagreement between the two leaders in the case of US claims of Soviet's arms sales to Central America, and the Soviet offer of the reduction of the naval forces in the Mediterranean. The other results of the summit mentioned are: The leaders' agreement on the issues related with the Lebanon problem, reduction of long range nuclear weapons, Bush's proposal that the foreign ministers of of both countries should meet and that the leaders should meet again, the prevention of chemical weapon production, control of nuclear testing, implementation of an open policy on defense issues, US proposal of granting observer status to Soviet Union in the GATT and priorities in trade relations with the US and the meeting of the leaders with their individual pacts.

Differences in topics can be seen however in the content and coverage of background topics. Cumhuriyet, Güneş and, to a lesser extent, Milliyet include more background than the other papers and have news items fully devoted to it. A considerable difference, however, can be seen in 
their content. Cumhuriyet (opinion) and Güneş (opinion) in particular, but also Milliyet (quasi opinion-quasi popular), provide coverage of the background of US-Soviet relations, the political structuring of Europe and the world, the dynamics of the summit context and the position occupied by Turkey within that context. In these papers the problem of re-unification of the two Germanies and the dissolution of the Eastern Bloc, the position of the EC for the future, especially in dealing with the future of Eastern Bloc and economic aid by wealthier members and as pre-summit topics. The establishing parallelism between the Yalta Conference and Malta Summit are also prominent background news topics.

On the other hand, the opinion paper Tercüman provides no background coverage and only a few context stories, about the pre-summit worry of the Eurepean countries. Background topics covered by Hürriyet (popular) concerned James Baker's statement with regard to the regional problems experienced by two powers, the dissolution of the Eastern Block and the cold war era. The problem of German re-unification is also featured in Günaydın's (popular) treatment of the background of the summit, in addition to the joint statement by Bush and Gorbachev that the two powers will redefine the borders of Europe. Sabah (popular), on the other hand, included background news concerning the mutual fears of the two superpowers and a chronology of previous summit meetings.

\section{Assessment of thematic analysis}

Generally, the thematic structure of the news items anayzed was seen to be dominated by the macropropositions, "New Era with Malta", "Turning Point in International Peace" and "Warm Meeting" feature prominently in headlines. Other dominant topics, as previously noted, concerned the details of the realization of the summit. By way of conclusion it can be asserted that thematically there are no major differences between the Turkish opinion and popular newspapers selected for analysis. What differences ther are can be seen in the provision of background to the main event. Cumhuriyet (opinion), Güneş (opinion) and, to some extent, Milliyet (quasi opinionquasi popular) all give background information to a certain degree while the coverage of Tercüman (opinion), and the popular papers can be characterized by it's lack.

\section{Schematic analysis}

The aim of this part of study is to examine the the schematic structures of the overall organization of the news items. It is intended to show which conventional news categories are present and in what quantity. While headline, lead and main event are obligatory in all news stories consequence, context, history, verbal reactions, expectations and evaluations remain optional. Those optional categories enrich the coverage and it is expected that the opinion papers, aimed at a more educated readership, should feature then more often, especially in relation to context and the history. Table 2 shows the number of schematic categories. 
Table 2. Schematic Categories

\begin{tabular}{|c|c|c|c|c|c|c|c|}
\hline \multirow{2}{*}{$\begin{array}{l}\text { Schematic } \\
\text { Categories }\end{array}$} & \multicolumn{7}{|c|}{ Newspapers } \\
\hline & $\begin{array}{c}\text { Cumhuriyet } \\
\text { (Opinion) }\end{array}$ & $\begin{array}{c}\text { Güneş } \\
\text { (Opinion) }\end{array}$ & $\begin{array}{l}\text { Tercüman } \\
\text { (Opinion) }\end{array}$ & $\begin{array}{l}\text { Miliyet } \\
\text { (Quasi } \\
\text { Op/Pop) }\end{array}$ & $\begin{array}{l}\text { Hürriyet } \\
\text { (Popular) }\end{array}$ & $\begin{array}{c}\text { Sabah } \\
\text { (Popular) }\end{array}$ & $\begin{array}{l}\text { Günaydın } \\
\text { (Popular) }\end{array}$ \\
\hline \multicolumn{8}{|l|}{ Headline } \\
\hline \multicolumn{8}{|l|}{ Lead } \\
\hline Main Event & 27 & 18 & 15 & 22 & 21 & 25 & 16 \\
\hline Consequence & 2 & 4 & - & 2 & - & - & 6 \\
\hline Context & 23 & 20 & 3 & 8 & 9 & 6 & 6 \\
\hline History & 6 & 7 & - & 1 & 1 & 1 & - \\
\hline Verbal Reac. & 7 & 9 & 3 & 13 & 8 & 10 & 6 \\
\hline Expectations & - & 5 & - & - & - & 1 & - \\
\hline Evaluations & 1 & 8 & - & - & 1 & 4 & - \\
\hline
\end{tabular}

Schematic categories of the news discourses of the selected papers and their numbers as follows: Cumhuriyet (opinion) has 27 main event, 23 context, 7 verbal reactions, 6 history, 2 consequence, 1 evaluation. Güneş (opinion) has 18 main event, 29 context, 9 verbal reactions, 7 history, 8 evaluation, 4 consequenses. Tercüman (opinion) has 15 main event, 3 context, 3 verbal reaction. Milliyet (quasi opinion-quasi popular) has 22 main event, 9 context, 8 verbal reactions, 1 history and 1 evaluation topics. Hürriyet (popular) has 21 main event, 9 context, 8 verbal reactions, 1 history, 1 evaluation topics. Sabah (popular) also has 25 main event, 10 verbal reactions, 6 context, 4 evaluations, 1 history and 1 expectation topics. Lastly, Günaydın (popular) has 16 main event, 6 context, 6 consequence and 6 verbal reactions topics.

It can be seen that, except the opinion paper Tercüman which lacks four of categories, the opinion papers mobilise all the categories of news topics. Schematically, it is clear that Tercüman does not display the categories expected of opinion papers and Milliyet, occupying as it does middle ground between two categories of papers, does not vary so very much from the popular papers. With regard to the quantity of the context and history topics which shows the richness of the knowledge that exists in the news discourses; there is a considerable difference between the opinion papers, Cumhuriyet and Güneş and other papers selected for analysis. Cumhuriyet has 23 context and 6 history topics and Güneş has 20 context and 7 history topics in this sense.

\section{Microstructural analysis}

\section{Analysis of local semantics}

The aim of this part of the study is to analyze which kinds of specification topics the selected newspapers feature. Specification topics relate both the main event and the background to the event. Quantatively, specifation topics carried in the sampled newspapers as follows: Cumhuriyet (opinion) 84, Güneş (opinion) 70, Tercüman (opinion) 25, Milliyet (quasi opinion-quasi popular) 36, Hürriyet (popular) 30, Sabah (popular) 33, Günaydın (popular) 7. As can be seen, except 
Tercüman, opinion papers (Cumhuriyet and Güneş) have more specification topic at the microstructural level.

Table 3. Number of Specifation Topics

\begin{tabular}{ccc}
\multicolumn{2}{c}{ Newspapers } & Number of Specifation Topics \\
\hline Cumhuriyet & (Opinion) & 84 \\
Güneş & (Opinion) & 70 \\
Tercüman & (Opinion) & 25 \\
Milliyet & (Quasi Op/Pop) & 36 \\
Hürriyet & (Popular) & 30 \\
Sabah & (Popular) & 33 \\
Günaydın & (Popular) & 7 \\
\hline
\end{tabular}

The specification topics appearing in Cumhuriyet concerned both the main event and background news. The main event topics covered were the agenda, site, preperations and security conditions for the summit, wheather conditions, and the content of the post-summit statements made by the two leaders on ending the cold war and entering into the new era on the issues of disarmanent and on improving US-Soviet relationship; their disagreement over of the US claim of Soviet's arms sales to Central America; the Soviet's offer of reduction of naval forces in Mediterraean; improvement of trade relationships between the US and the Soviet Union; and announing declaring the future meeting of NATO and Warsaw Pact.

Background topics appearing in news discourses of Cumhuriyet were as follows: German reunification, the dissolution of the Eastern Block and its effects on Turkey, underlining of the Cold War Era, the instrinsic features of the Malta Summit, the Yalta Conference and its consequences, Western Eurepean expectations from the US and Soviet union, the possible meeting of Western leaders in Helsinki and desire of the wealthier Western eurepean countries to grant economic aid to the Eastern Bloc.

The specification topics appearing in Güneş concerning the main event are similar to those in Cumhuriyet. Background topics concern East-West detante, political relations between Kohl and Mitterand, the presss coverage of the summit in France, background of the Us-Soviet relations since 1985 and the effects of the summit on Turkey.

Tercüman (opinion): In addition to the specification topics concerning the main event, specification topics related to the context of the news event focus on European worry about the summit and the journey of Raisa Gorbachev to the island.

Milliyet (quasi opinion-quasi popular): Specification topics concerned with the main event are nearly same as for the other papers' topics. Background topics are about 'US-Soviet propaganda war', Gorbachev's pre-summit statement on naval forces in the Mediterranean, Soviet trade relations, and details of an interview an ex-foreign minister of Turkey.

Hürriyet (popular): Background topics of the news discourses of the Hürriyet are about the US foreign minister's statement concerning regional problems faced by the superpower and Gorbachev's pre-summit statement on the naval forces in the Mediterranean. 
Sabah (popular): Background topics concern the dissolution of the Eastern Bloc and US and Soviet supicions concerning the summit.

Günaydın (popular): Specification topics focus only on the main event and about the outcome of the summit, the Latin America problem, disarmanent, the possibility of the Soviet membership of GATT, the holding of the Olyimpic Games in Berlin.

\section{Analysis of local coherence}

The coherence link between the news topics of the selected papers is established by a functional link established by the top-to-bottom organization of the news stories by specification topics. News reports are observed to begin with categories of circumstance or consequence and with the results or further circumstance and consequence. This arrangment is not seen to differ either in the opinion or popular papers.

\section{Rhetorical Operations}

\section{Analysis of lexical style}

In this part of study, the lexical style of the headlines employed by the selected papers will be discussed. Firstly, it should be underlined that the all the papers describe the post - summit positively with lexical preferences such as "opening of the new era", "detante" and "end of Cold War". The preferred positive words and metaphors-working to strenghten the rhetoric of the news discourses include; happy end, new world, warm meeting, permanent peace, warm winds, peace, happy, new peace, turning point, honeymoon, hot meeting, hope, breeze, love boat, glad (see the full headlines quoted earlier). With these lexical preferences, papers construct the 'discourse of the peace' and the 'new world' which presents a future for World politics based on multi-polarity. To construct this meaning, for instance Milliyet uses the headline "Malta Breeze in NATO and Warsaw Pact" (Dec 5, 1989). In contrast, the one lexical preference of the popular and liberal paper Hürriyet is expressed in the post-summit headline: "Soviets summit to liberal economy" (Dec 5, 1989) emphasising the demise of the Soviet socialist economic path. The news text of this headline is about the possible economic aid of Us to Soviet Union.

In case of the pre-summit lexical preferences, some newspapers-Cumhuriyet (opinion), Milliyet (quasi opinion-quasi popular), Günaydın (popular) use the words of "superpowers", "barganing" and "From Yalta to Malta". Here we see evoked the expectations that the two superpowers share the world as they did at the Yalta Summit', using the parallesim as a rhetorical operation. Milliyet uses the pharese of, "Eyes of Superpowers on their Gardens" (Dec 1, 1989) and "Attention to Yalta Syndrome" (Dec 3, 1989) which positions of US and Soviet Union within in the Cold War Era. In our the collective memory of the Cold War period, by the term 'garden' we understand that they argue about problems of their blocs. Here the metaphor of garden, refers especially to the their conflict on the issues of Soviet arms selling to Central America and the Soviet' offer of a reduction of naval forces in the Mediterranen. The lexical preferences of the all papers in their headlines present a common undersatnding that the leaders of the two superpowers will shape and determine the share and direction of world politics, as in the case of the past. 
The another pre-summit lexicalization, which is preferred by the opinion paper Cumhuriyet, is about 'Eurepean Community's suspicion about the summit' with the headline of "EC following the summit with suspicion" (Dec 3, 1989). There are some lexical preferences related with Turkey too. One, from the opinion paper, Cumhuriyet states that "Ankara looking at the summit with suspicion" (Dec 2, 1989). Two other lexical prefences concerning Turkey are caried the opinion paper Güneş- “Where is Turkey in Malta?" (Dec 5, 1989) and “Turkey's four suspicions" (Dec 5, 1989). The only other lexical preference about Turkey is presented by the popular paper Günaydın: "Quit NATO and look to Europe" (Dec 5, 1989). Turkey is not mentioned here by name but the clear implication is that, under the changed circumstances, Turkey shoud look to Europe rather han to the US dominated NATO bloc.

Europe appears again inthe pre-summit headline and lexical preference carried in Günaydin's headline: "Sweeping Europe clear again" (Dec 3, 1989). The word "again" is a clear reminder of the past, but one that can be read in one of two ways. On the one hand it could be interpreted as the meaning that the two superpowers are once again designing the future of Europe as they did at Yalta at the end of the Second World War. On he other hand, it is also open to an alternative, more positive reading, that the political position of Europe and the $\mathrm{EC}$ will be strengthened through the dissolution of the Eastern Bloc and unification of the two Germanies.

Another pre-summit lexical preference in Günaydın is "Two knots in the summit" (Dec 3, 1989). Here we again. A metaphor, knots strengten the rhetoric of a news discourse. It is clear that the "two knots" refer to the conflictual issues around disarmanent- US claim that the Soviets are selling arms to Central America and the Soviet offer of a reduction in the naval forces in Mediterranean.

As a popular paper, Günaydın, together with the other popular papers in the sample, Hürriyet and Sabah, prefer to employ informal and vernacular lexical preferences such as love-boat and honeymoon, in line with their strategy of reaching readers by presenting information as entertainment.

\section{Analysis of the photographs}

With the exception of the photograph of the Mikhael Gorbachev and Raisa Gorbachev laughing, which featured in Tercüman, the other papers' photographs of Malta Submit news divide into two categories: "pre-summit photographs" and "post-summit photographs".

The post-summit photographs are dominated by images of the leaders (Bush and Gorbachev) laughing and shaking hands, in keeping with the general mode of optimism which followed the meeting. Post-summit photographs are compatible with the post-summit headlines and lexical preferences of the headlines: The World is being renewed (Cumhuriyet, Dec 4, 1989); Happy ending to the supers' summits (Güneş, Dec 5, 1989); New era with Malta (Güneş, Dec 2, 1989); Hope for the World (Milliyet, Dec 4, 1989); Broadside of peace in Malta (Hürriyet, Dec 1, 1989); Yes to peace (Günaydın, Dec 4, 1989); Everyone is happy (Günaydın, Dec 5, 1989). These postsummit photographs are strengtening the common discourse construction of the papers of the opening of the new era", "detante" and "end of Cold War". 
The pre-summit photographs however focus on the US and Soviet warshiphs. Their denotative meaning indicates the 'venue' of the summit, on an island surrounded by sea. But they also evoke strong collective memories of the 'Cold War' and 'armament'. As I mentioned before, they are deployed, like other rhetorical operations, to make news text more persusive. Although the headlines present an end to hostilities and herald a new era of detente the coverage of the event also suggests that the US and the Soviet Union will continue as the dominant global military powers.

\section{CONCLUSION}

As mentioned in the introduction, media play a key role of storing, retrieving, reactivating, preserving and shaping collective memories. Consequently, as Zelizer notes, "as journalism continues to function as one of contemporary society's main institutions of recording and remembering, we need to invest more efforts in understanding how it remembers and why it remembers and why it remembers in the ways that it does" (quoted in Olick, 2014: 17).

I have argued here that Van Dijk's (1988a; 1988b) sociocognitive theory of news production is one useful resources we can draw on in developing these efforts, particularly since he assigns memory an important role. According to van Dijk's arguments, news perception and interpretation is a subjective but socialy organised by the memory of an observing reporter or editor and that journalists participate in news encounters and write news articles as social members.

Pursuing this perception the sociocognitive theory of news production explores how texts or event information is analyzed, interpreted and represented in cognitively designed memory. Van Dijk (1988a: 14) introduces the theoretical term semantic macrostructures to capture that important aspect of discourse and discourse processing and underlines their importance in organising storage and memorization for both the reporters and editors and media users.

Macrostructures explain how newsmakers continuously and routinely summarize the myriad of source texts (other media messages, wires, interviews, reports, or press conferences) that are used in the production of a specific news reports. Macrostructures also explain why most readers usually only remember the main topics, that is, the higher levels of the macrostructure of a news reports. According to van Dijk (1988a: 15), since macrostructures are derived for or from a text on the basis of our pre-existing knowledge and beliefs, they are social located so that the most important information of a news event for one person or group may not be so for another.

The top of the macrostructure of a news report generally tends to be expressed first in the headline (the highest macroproposition), then the lead (the top of the macrostructure), and subsequently the lower macropropositions of the report, with details of content and the less prominent schematic categories (e.g., history or comments) towards the end. This allows stylistic variation by each reporter or newspaper. For the reader it means that in principle the beginning of the text always contains the most important information (van Dijk, 1988a: 15).

In the case of the analysis of the news discourses on the Malta Summit we found that, the headlines of "New World", "Cold War Ended" and "Happy End" are preferred. In case of the pre-summit headlines however we are faced lexicalization that evokes conflict and the logic of the Cold War- "superpowers", "from Yalta to Malta" and "EC following the summit with suspicion". 
In case of the lexical preferences, we again find two types of meaning constructions: one presummit and the other post-summit. The pre-summit lexicalization emphasises suspicions over the possibility that the summit is another instance of superpower barganing, as in the Cold War Era, with major consequences for the future of Europe ("Sweeping Europe clear again": Günaydin, Dec 3, 1989) ). In contrast, the lexical preferences of the post-summit coverage present a dominant meaning construction based on optimism; "new world", "end of Cold War", "hope", "warm meeting" - in short 'new world and the end of Cold War'.

The choosen photographs of the summit are compatible with this division in meaning construction of the news discourses The pre-summit photographs evoke the 'Cold War' and 'armament' with the signifiers of the "warships". The post-summit photographs evoke the 'new era', and the 'end of Cold War' and 'peace' with the signifiers of the leaders' shaking hands and laughing.

When we evaluate the news discourses of Malta Summit of the selected papers; we need to discuss that firstly, why the papers have the same discourses and secondly, whether journalists construct the collective memories or journalists' discourses are determined by the collective memories.

The papers' similiar discourses can be explained with the van Dijk's notion of the "journalistic code", the shared ideology of journalists' news making which was established by the Western media and news agencies and then spread around the World, including Turkey. Ottoman-Turkish modernization was mainly based on models of westernization and was realized by a top-down modernizing elite of which journalists were a part. Consequently, the values of westernization, including the dominant conception of news values, have been promoted by Turkish journalists from the beginning, as in the case of the Jenue Turks. In the case of international news, sharing western news discources is futher strengthened by the fact that it draws heavily on international news sources.

When we ask whether journalists construct our collective memories or are shaped by them, the answer is both. Journalists construct our collective memories by providing first drafts of history through the ways they organise news reports, but if they are to engage with readers, they also need to resonate with and activate the collective memories of the society. As the material presented here shows, these memories activate anxieties as well as hopes with the pre-summit coverage drawing on memories of the "Cold War" and "conflict" and the post-summit coverage welcoming a resolution and the begining of a "New World" and the "End of the Cold War".

This presentation follows a clear narrative arc. It begins with doubts and concerns that the summit is simply a repeat of the past, organised around entrenched antagonisms and familiar strategies for securing avantage in the contest between the two superpowers, as at the Yalta meeting at the end of World War II. It ends with an affirmation of a genuine break with the past and the possibilities of new era of peace and detente.

\section{BIBLIOGRAPHY}

Connerton, P. (1999). Toplumlar nasıl anımsar? Çev. A. Şenel. İstanbul: Ayrıntı.

Halbwachs, M. (1992). On collective memory. Chicago, IL: Chicago University Press. 
Hoskins, A. \& O’Loughlin, B. (2010). War and media: the emergence of diffused war. Cambridge, UK: Polity Press.

Huyssen, A. (1999). Alacakaranlık anıları. Çev. K. Atakay. İstanbul: Metis.

Huyssen, A. (2000). Present pasts: media, politics, amnesia. Public Culture, 12 (1): 21-38.

Maltby, S. (2016). Media-remembering the Falklands War: subjectivity and identification. International Journal of Communication, 10: 642-659.

Misztal, A. B. (2003). Theories of social remembering. Maidennnnead, Philadelphia: Open University Press.

Olick, J. K. (2014). Reflections on the underdeveloped relations between journalism and memory studies. In B. Zelizer \& K. T. Weinblatt (eds.), Journalism and memory (pp. 17-32). New York: Palgrave Macmillan.

van Dijk, Teun A. (1988a). News analysis. New Jersey: Lawrence Earlbaum Associates Publication.

van Dijk, Teun A. (1988b). News as discourse. New Jersey: Lawrence Earlbaum Associates Publication.

van Dijk, Teun A. (2011). Discourse studies: a multidisciplinary introduction. London: Sage.

Zelizer, B. (1992). Covering the body: the Kennedy assassination, the media, and the shaping of collective memory. Chicago, IL: University of Chicago Press.

Zelizer, B. \& K. T. Weinblatt (2014). Journalism and memory. New York: Palgrave Macmillan. 